\title{
Anti-Corruption from the Perspective of Ho Chi Minh's Ideology: Towards a Vietnamese Rule of Law
}

\author{
Lai Quoc Khanh/Nguyen Ngoc Anh
}

According to the UN Convention against corruption in 2003, "corruption is the abuse of state power for personal interests." Section 1 of Article 2 in the Vietnam anti-corruption law in 2005 states that: "Corruption is the behavior of an official who abuses his/her rights and position for personal gains." The Dictionary of Law indicates:

"Corruption is the exploitation of one's position and rights to gain illegitimate interests, which causes damage to the properties of State, organization, individuals and infringes on the activities of public authorities. "'

Despite its different interpretations, corruption is commonly understood on a global level as the abuse of one's position and rights for personal interests through illegal behaviors, in other words, the dishonest use or appropriation of public power or collective resources. During feudalism in Vietnam, corruption was reflected in the custom of donating, bribing and giving presents to mandarins and colonial officials. Through time, it became a social evil and a bad custom that denigrated the social structure to its core.

Recognizing anti-corruption as an insidious and long-term problem of the country, since the August Revolution 1945, apart from encouraging diligence, frugality, integrity and righteousness (Cần, kiệm, liêm, chính) among party members and the people, party, state, government and President Ho Chi Minh were particularly concerned about the struggle against corruption, misappropriation and abuse of power. Corruption, misappropriation and abuse of power

\footnotetext{
${ }^{1}$ General Vietnamese Dictionary (1998), 695.
} 
have a broad range of meaning under the framework of Ho Chi Minh's ideology. In this paper we would like to shed light on the issue of corruption according to Ho Chi Minh and relate it to the development of a Vietnamese socialist rule of law.

\section{Ho Chi Minh's Ideas on Corruption and Anti-corruption}

\section{Definition and Concept of Corruption under Ho Chi Minh's Ideas}

Ho Chi Minh's anti-corruption ideas constitute an important part of his ideology. The main features and contents of his ideas on anti-corruption have been adopted by party, state and Vietnamese population as a whole in the battle against corruption today.

President Ho Chi Minh is an excellent leader and warrior in Vietnam's liberation movements in the $20^{\text {th }}$ century, and is also a pioneer and director in anti-corruption efforts - a global issue. Ho Chi Minh is one the few leaders who relentlessly and resolutely committed himself to battling corruption during his revolutionary career. Ho Chi Minh continuously maintains a critical standpoint towards corruption in former colonial and imperial systems and also their new counterparts.

His synchronicity between words and deeds through resolute anticorruption acts and being an example of "diligence, frugality, integrity and righteousness" constitute the exceptionality of Ho Chi Minh's ideology and his ideas on anti-corruption in particular. Ho Chi Minh clarifies the role of mitigating corruption, misappropriation and abuse of power, considering it an important task for Party's members and the people:

"Corruption, misappropriation and abuse of power are social evils. They must be erased in the pursuit of diligence, frugality, integrity and righteousness, to encourage production and an economical lifestyle, to lead our national salvation to victory and success, and to nourish ethical practices among the entire population. This is an important task of every one of us. "2

\footnotetext{
${ }^{2}$ Collection of Ho Chi Minh works (2000), 534.
} 
The battle against corruption, misappropriation and abuse of power is a permanent and great concern of Ho Chi Minh, who considers them "most debasing and appalling behaviors." 3 The nature of misappropriation is "To steal from the public, which is equivalent to deception and greed", and is "no less than robbery". President Ho Chi Minh produces a conceptualization of misappropriation:

"Concerning public servants, misappropriation (tham ô) means to steal from the public; to starve the people; to rob from the army. He who misappropriates secretly misuses public funds, and also appropriates the State's properties to entich his own division and local area. Concerning the people, misappropriation means to steal from the public, to lie and avoid tax."

Ho Chi Minh considers the nature of misappropriation as "to steal from the public" - i.e. to steal public properties contributed by the people not in order to fulfill collective tasks but to enrich oneself or even one's inner circle. Any misuse of "public properties" as "private properties" is considered by Ho Chi Minh an act of misappropriation. This is its general meaning. In this sense, the parties involved in misappropriation include not only public servants, who hold certain power in the political system, but also ordinary citizens who "embezzle, lie and avoid tax". More importantly, Ho Chi Minh reveals a more subtle and sophisticated kind of misappropriation, namely indirect misappropriation. He provides an example of this practice:

"any public official or citizen who receives a monthly wage yet is irresponsible, greedy, sluggish, and wasteful of the time of the Government and others. "'

This is a special kind of misappropriation. Though not liable to cause serious damage as direct misappropriation, this kind happens on a regular, daily basis and proves to be devastating to the efficiency of public authorities and state management, which greatly threatens the national revolutionary project. Similar to misappropriation, extravagance is considered by Ho Chi Minh as misconduct in the eyes of the population. Extravagance is caused by public servants, military servicemen, factories and citizens who irresponsibly waste or misuse time, wealth and labor. He makes clear:

\footnotetext{
${ }^{3}$ Collection of Ho Chi Minh works (2000), 110.

${ }^{4}$ Collection of Ho Chi Minh works (2000), 488

${ }^{5}$ Collection of Ho Chi Minh works (2000), 436.
} 
"Some say that extravagance is not as bad a conduct as misappropriation. In fact, they are two different acts, but both deplete the resources of the Government and the people."

Ho Chi Minh even states that extravagance is more threatening than misappropriation, because "it is more common." He indicates three kinds of extravagance: "extravagance of labor", "extravagance of time", and "extravagance of wealth". While each has its own forms and different manifestations, they all lead to consequences which "maybe even more serious than caused by misappropriation", damaging the properties of Government, people and disrupting the national liberation and construction as a whole.

Both misappropriation and extravagance are dangerous illnesses. To effectively combat these, it is necessary to understand their causes and origins. Ho Chi Minh says: "Misappropriation and extravagance both result from the abuse of power." He makes clear that abuse of power (quan liêu) directly leads to and accelerates the two former. He insists that whenever abuses of power show up, there are misappropriation and extravagance and vice versa. President Ho Chi Minh thoroughly analyzes the nature, causes and symptoms of abuse of power. According to him, it takes the form of

"unnecessary bureaucratic rules and red tape, detachment from and mistreatment of the masses, and disobedience of the policies set out by the Party and Political Organizations."

Abuse of power can mean willful ignorance of one's own tasks, failing to acknowledge general affairs, and providing insufficient and obscure instructions. It can also mean alienation towards the masses, lack of knowledge of subordinates' performance, denial of feedback, and avoidance of criticism and self-criticism. The overall manner of an abuser of power is undemocratic and disrespectful of the principle of "collective leadership-individual duty" (lãnh đạo tập thể, phân công phụ trách). Ho Chi Minh characterizes it as

"to focus on the formalities of every task without going into its substance, and to only report, instruct and inform on the surface without making thorough and sufficient investigations. ${ }^{\text {"x }}$

\footnotetext{
${ }^{6}$ Collection of Ho Chi Minh works (2000), 436.

${ }^{7}$ Collection of Ho Chi Minh works (2000), 394.

${ }^{8}$ Collection of Ho Chi Minh works (2000), 394.

${ }^{9}$ Collection of Ho Chi Minh works (2000), 489.
} 
In performing his own duty or delegating tasks to subordinates, without proper supervision, it is not possible for an official to instruct and oversee his subordinates; and by failing to make timely correction of wrongdoings, he causes the loss of wealth and resources of the state and people. Ho Chi Minh writes:

"Abuse of power can mean that public authorities at different levels and sectors fail to oversee themselves, their subordinates and the masses. It is the seed of misappropriation and extravagance. Therefore, to combat misappropriation and extravagance, we must prevent abuse of power. But this has to be done with enough preparation, planning and clear objectives. In every sector and every area, public officials, people and servicemen must be informed about these bad practices. "10

According to Ho Chi Minh, public servants and authorities who abuse their power are so blind and numb that they fail to maintain overall regulations and self-discipline. As a result, they become wrongdoers who drown themselves in misappropriation and extravagance. This leads to a consequence in which not only these officials practice misappropriation and extravagance for their own interests, they fail to maintain overall management and administration and inspire corrupting behaviors among their own subordinates, causing loss and damage to the resources and time of the State and the people.

Ho Chi Minh deems these bad practices "allies of the colonists and feudalists", and "enemies of the people, army and Government." ${ }^{11}$ For these practices are disrupting. First and foremost, they drain public properties. Many officials are in charge of public properties donated by the State, the people and foreign partners, which are used to serve revolutionary efforts and improve living conditions. Due to their egoism and desire for personal gains, these officials take from the public and misuse common possessions of the State, threatening the cause of national construction and diminishing overall living standards. By abusing power and neglecting responsibilities, they exhaust the wealth, time and resources of the State and people. While not directly leading to robbery and embezzlement, extravagance happens on a regular basis and in different forms and cause just as much damage as misappropriation.

Misappropriation and extravagance debase and corrupt the moral consciousness of an official and diminish his lucidity and enthusiasm, causing popular skepticism towards party and state. Ho Chi Minh affirms that most of

\footnotetext{
${ }^{10}$ Collection of Ho Chi Minh works (2000), 436.

${ }^{11}$ Collection of Ho Chi Minh works (2000), 490.
} 
Vietnamese party members, union members, public servants and staff are clean and devoted, commit to the revolutionary spirit and practice diligence, frugality, integrity and righteousness. They are willing to endure hardship and sacrifice for revolutionary efforts and popular aspirations. However, among them there are still a number who practice misappropriation, abuse of power and extravagance for their own sake, thereby corrupting and alienating themselves from moral principles. This discourages the Party, spoils the reputation of party and state and threatens revolutionary efforts. Ho Chi Minh makes clear: "the battle against misappropriation, extravagance and abuse of power must rely on the masses to be successful."12 The participation of the masses determines its accomplishment. The more they actively contribute to it, the more it is likely to succeed. Ho Chi Minh confirms that "the more people participate, the more its victory is complete and timely."13

The prevention of misappropriation and extravagance is extremely important and must be regularly addressed at all levels and by different sectors. Like in other areas, to be successful in the area of anti-misappropriation and anti-extravagance; we must be aware of the instructions that lead us in this struggle. Ho Chi Minh emphasizes: "it is necessary to be prepared by making plans, and thus leadership, organization and loyalty are needed." ${ }^{14}$

\section{Causes, Origins and Conditions of Corruption}

At the objective level, Ho Chi Minh considers misappropriation and extravagance "serious diseases" of any state. Whether in feudal, capitalist or socialist state, without thorough education and if state activities are conducted without the supervision and control of the people, it is not difficult for these two practices to occur: Those who hold authority, whether influential or not, are likely to be corrupt. Ho Chi Minh makes clear:

"Those who work for public organs from Central level to grassroots level are more or less endowed with power, and thus are more likely to be wealthy through robbing the Government or stealing from the people. Without maintaining diligence, frugality, integrity and righteousness and impartiality, they are easily spoiled and become robbers in the eyes of the people."

\footnotetext{
${ }^{12}$ Collection of Ho Chi Minh works (2000), 495.

${ }^{13}$ Collection of Ho Chi Minh works (2000), 490.

${ }^{14}$ Collection of Ho Chi Minh works (2000), 490.
} 
At the subjective level, "appropriation is caused by the lack of moral consciousness and egoism" among public servants and cadres. Ho Chi Minh writes: "Egoism is such an effective virus that causes various illnesses, for instance sluggishness, cynicism, greed, opportunism, abuse of authority, misappropriation, debasement, wastefulness and extravagance. It also diminishes solidarity, self-discipline and ignites whimsicality, the defiance of State and Party's policies, and inhibits revolutionary and popular efforts. By and large, egoism may lead to various frauds." Ho Chi Minh says that abuse of power is the root of misappropriation and extravagance. All of these bad practices are the enemies of the people, army and Government. Insidious as they are, for they carry no weapons and yet penetrate our organizations to disrupt our tasks, dishearten and demoralize our men, and prevent them from practicing diligence, frugality, integrity and righteousness. They are "internal invaders" and enemies within. Therefore, "the battle against misappropriation, extravagance and abuse of power is as important and volatile as military battles. This is a battle in ideological and political fields.

These practices can also be caused by the lack of knowledge and education and generally the inadequate management of the state. Therefore, to combat them, it is necessary to improve both the moral quality of public servants and administration and organization of the state.

\section{Ho Chi Minh's Viewpoints on Anti-Corruption Solutions}

Having been aware of the insidious nature as well as the causes of misappropriation, extravagance and abuse of power, Ho Chi Minh proposes a set of solutions to prevent these acts.

In preventing these practices, Ho Chi Minh is particularly concerned about improving overall awareness among the masses. That is, "to make the masses aware of the danger of misappropriation, extravagance and abuse of power; to transform hundreds of vigilant eyes and ears into omnipresent supervisors who prevent the occurrence of these acts." ${ }^{15}$ To prevent misappropriation, extravagance and abuse of power, the masses supervise public servants by quickly identifying illegal behaviors and criticizing and denigrating their bad conducts. Thorough supervision of the masses over public servants through different methods is an efficient way to prevent these practices. In addition, timely

${ }^{15}$ Collection of Ho Chi Minh works (2000), 576. 
comments and complaints made by the masses help relevant authorities to quickly discover bad behavior and produce appropriate penalties. Ho Chi Minh says that misappropriation and extravagance are caused by egoism and abuse of power. This literally means to focus on appropriating and self-indulgence without any concern for moral improvement and professional performance, to be ignorant of the aspirations and demands of subordinates and citizens, and a general avoidance of supervision and criticism. The prevention of egoism and abuse of power is most useful in combating misappropriation and extravagance. Ho Chi Minh instructs that:

"Our Party should do its best to educate its members about communist ideals, missions and policies and about their tasks and ethical requirements."

A public official is supposed to be aware of his position as 'servant' of the people and revolutionary goals, to put his own interests below that of the revolution, the Party and the people, be devoted and thorough in his tasks, be open to the masses, respect and promote people's mastery and improve the collective spirit and self-discipline. He must continuously pursue personal growth and improve his knowledge through various ways from reading books to learning from his superiors, subordinates and the populace.

According to Ho Chi Minh, a public servant must be a good example of dedication, purity, resilience and morality; and follow diligence, frugality, integrity and righteousness. Ho Chi Minh writes:

"To maintain purity and stay away from corruption, it is necessary to practice the four virtues on a regular basis, namely diligence, frugality, integrity and righteousness. "17 He further explains:

"Diligence means to be productive in personal duties, whatever they are. Frugality means economical use of time. Integrity means to avoid misappropriation and protect public and common properties at all cost. Righteousness means to evade every bad practice and follow every good practice. $" 18$

He then requires and instructs public officials to practice these virtues and consider them must-have qualities of a revolutionary servant. Second, it is

\footnotetext{
${ }^{16}$ Collection of Ho Chi Minh works (2000), 439.

${ }^{17}$ Collection of Ho Chi Minh works (2000), 347.

${ }^{18}$ Collection of Ho Chi Minh works (2000), 392.
} 
necessary to practice democracy and maximize the people's mastery by leaning on them. Ho Chi Minh writes:

"What is democracy? It means the people are masters. So what are the President, Ministers, Deputy Ministers and other public members? Servants! They are servants of the people and not revolutionary elite. The maintenance of democracy is the key to every difficulty".

He emphasizes that only when the entire population takes part in realizing and implementing the motto "the people know, the people discuss, the people perform, and the people check" can misappropriation, extravagance and abuse of power efficiency and actively be solved. President Ho Chi Minh asks the people to fulfill their mastery. He claims that "corruption among officials is caused by ignorance among people", therefore, the people must be aware of their power and know how to supervise public servants in practicing their integrity. When a house is robbed, everyone will be informed and all village members go out to catch the robber. Likewise, when a public possession is lost, everyone is responsible for informing on the culprit and punishing him because everyone is charged with protecting public properties. State properties are infrangible and thus their misuses mean the violation of common interests and an enemy. Public officials must do their best to maintain integrity. They must practice collective criticism and self-criticism to clear themselves of any desire for misappropriation, extravagance and abuse of power. A nation that knows how to maintain frugality and integrity is rich in both material and spiritual aspects and deserves to be regarded as civilized. He continuously emphasizes: "persistent anti-misappropriation is a common mission of the Party and the people". To this end, the Party launches the "Three pros and three cons", in which "the improvement of enthusiasm, consolidation of financial management and technical reforms" are the pros and "misappropriation, extravagance and abuse of power" are the cons (this campaign was launched in the 1960s).

Third, it is necessary to make constant state reforms and train and improve professional skills of public servants. This is a basis to develop a cost-effective and efficient government that fulfills and represents the people's power (through measures, policies and regulations) under their supervision; and also contributes to democratization and enhanced transparency. All during his presidency, Ho Chi Minh successfully trained ethical and capable public officials who were indeed "servants" of the people and devoted to the construction 
of a state of the people, by the people and for the people. He himself is the best example of a morally-conscious person who practices "diligence, frugality, integrity, righteousness and impartiality" and combines words and deeds.

While Ho Chi Minh has a "reservoir of affection" for the entire Party, people and army, he stops at nothing to realize his resolute and unyielding anticorruption project. President Ho Chi Minh, having been through "sleepless" nights, decided to execute Colonel Tran Du Chau, a quartermaster general who misused a large amount of the army's funds in trivial pursuits, while the entire population was struggling to expel the French colonists. This case is but a past event yet retains its value today.

\section{Ho Chi Minh's Anti-Corruption Ideas in the Development of Vietnamese Rule of Law Today}

Thanks to the party-led renovation, Vietnam has gained important economic achievements. Socio-economic developments improve living standards while national security is ensured. Nevertheless, we are faced by serious challenges and difficulties. One of the obstacles to renovation is corruption. Corruption and extravagance are becoming more complicated and lasting, causing indignation among the people and huge losses for the state, deflecting the integrity of party members and public officials and compromising social justice and equality.Being aware of this situation, party and state have released many resolutions to reduce corruption and gained preliminary results. However, corruption has become more prevalent than before and appears to expand to every sector, industry and area. Clearly, a better understanding of the nature and causes of corruption is necessary in order to create better solutions. Among anti-corruption solutions, preventive measures are also important due to the following reasons:

- First, if applied on a regular basis, these measures can produce a range of effects. By regularly and continually performing these measures, it is possible to attack corrupt behaviors at their root.

- Second, preventive measures can reduce the consequences of otherwise irreversible corrupt acts. Prevention means proactive anti-corruption and can minimize possible damage. This includes not only economic loss, which is numerical, but also the degradation of morality and in a broader sense, in- 
fringement of the laws and social justice, which causes skepticism among the people towards s state and party and our project of renovation.

- Third, the study and application of preventive measures contribute to the overall renewal and improvement of state management and governance in particular and socio-economic renovation in general.

\section{Regarding Party Members and Public Officials}

Every success in the national liberation and renovation in the past and present is attributed to the Communist Party's leadership. Its strength is reflected in the individual strength of its members. More than anyone, party members are supposed to be the pioneers of anti-corruption, especially with respect to those who currently hold important positions in the state. Anti-corruption is a battle against the temptation of material gains which becomes even more influential and powerful under the impact of a market economy. The ethical, political and ideological education of party members should not merely stops at decisions and resolutions but has to become a regular and important task of the party's organs and every conscious member.

The party has to instruct and supervise each member in improving his moral quality by fulfilling particular tasks and roles. Political education and moral improvement should not stop at slogans and have to include practical criteria based on which every party member can self-improve and party organs can evaluate its members plus provide necessary support.

\section{Promote the Supervision of Party Members}

This is especially important. What is needed is improved coordination between the party and state organs in managing public servants, as the party members account for most of the positions in the state, especially at senior level. The management of party members refers to an overall system of management, including recruitment, nomination, appointment and evaluation during their term. Mismanagement of party members easily enables possible opportunists to infiltrate the party and state and even claim the highest positions to pursue their personal gains. This is an especially complicated issue that requires a substantive understanding of the danger of irresponsible management and possible solutions in case there are errors. 


\section{Include Criticism and Self-criticism into Regular Party Activities}

Criticism and self-criticism are useful weapons of the party. "The Party should not seek to hide its mistakes or avoid criticism. The Party has to admit its mistakes and correct them to ameliorate and give example for public officials. It has to perform self-criticism and self-correction (...) The Party has to say no to self-indulgence, self-interests, arrogance and exaggeration." ${ }^{19}$ Criticism and self-criticism have been overall underrated and in some cases even neglected and bypassed. Every party member has to be conscious of his responsibilities and of self-criticism as an instrument to improve his own moral conducts and a weapon to prevent bad practices and opportunistic ideas. Moreover, not a few public officials and party members are aware of their responsibility to make honest and sincere feedback and criticism to the party and their comrades as pioneers of the working class. In some cases, criticism is misused as a tool in power struggle and conflict of position. These are disgraceful acts that need to be corrected so that criticism and self-criticism can contribute to improving and consolidating the morale of the party and preventing corruption.

\section{Improving Public Awareness}

This is what currently concerns the entire society and tests the ability of party and state in maintaining confidence among the populace. It is impossible to ask for popular confidence if a lawbreaker, especially a party member who produces corrupt behaviors, remains unpunished despite repeated accusation against him. Furthermore, a legal system is no longer legal if it allows important figures in the party and state to escape their punishment for having spread corruption within their own sector. It is understandable that the party aims to sustain political stability, but this does not mean we should ignore or tolerate those who spoil the party's image by disobeying the law and ignoring public interests. Public officials and servants, especially those higher-up, are put under the party's leadership and management. Thus, the party itself is in charge of punishing dishonest acts or irresponsible behaviors that can lead to corruption. A strict posture towards flawed party members increases the confidence in it and is also a useful preventive measure.

${ }^{19}$ Collection of Ho Chi Minh works (1995), 267-268. 


\section{Regarding State Organs}

Adjusting and improving state policies and regulations, especially on economic and financial management and public asset management is an efficient way to prevent corruption. As mentioned above, corruption tends to develop in particular socio-economic conditions. Loopholes in policies are the best perpetrator of corrupt behaviors. Thus, it is necessary to adjust and complete the system of state's policies, rules and regulations and to provide sufficient, clear and accessible regulations, first of all on economic, financial, land, public asset and service management. In addition, these policies and regulations have to be upheld and protected from being exploited by opportunists to acquire illegitimate rights and benefits.

Other tools are: promotion of state reforms by delegating clear and proper tasks for public officials, improving administrative reforms, removing unnecessary red tape and bureaucratic rules for businesses and citizens and publicizing administrative procedures. These measures are well recognized but it takes a step-by-step process to produce favorable results. The state, especially its administrative system, is gaining membership and becoming more and more complicated in terms of its functions and tasks due to objective reasons such as population growth and continuous expansion of socio-economic areas, thanks to technological advances. However, the fact remains that the quantity of administrative officials is not matched by their performance. This is a thoughtprovoking issue. The growing number of public organs as well as their functions and missions is sometimes not in line with socio-economic requirements or not based on scientific forecasting, instead it results from subjective calculation or even from the parochial thinking of certain local authorities. Therefore, it is necessary to reform the state by simplifying its organizational structure and clarifying relevant responsibilities of each administrative officer. In addition, unnecessary and opaque bureaucratic rules make way for the development of authoritative and haughty behaviors to the point where they become natural and public. Despite our efforts and solutions to improve administrative procedures as one of the strategic aspects of renovation, results are still limited. It is therefore necessary to further promote these reforms by regularly checking and removing unnecessary procedures that threaten public interests at every level and in every sector, especially the areas that most likely produce corruption.

The wage system must be reformed along with the improvement of the livelihood of salaried employees. Other measures include the punishment of 
corrupt behaviors and the improvement of political awareness, discipline and professional capacity among public officials and cadres. These are also important issues, because after all, any system or policy is created by human beings and the first reason to enter the workforce is for one's living, even for public servants. Justice is the first requirement of every public servant. But one cannot maintain justice if one is burdened with survival needs. It is unreasonable for us to ask for heartfelt service from public officials if they do not earn enough for their living. Therefore, while regularly educating officials about their responsibility, we have to accelerate the reforms of the wage system. The wage reform policy is gaining popularity among the population and expected to become one of the useful measures to prevent corruption.

The compliance with the regulations of party and state on the conduct of public officials is also an efficient anti-corruption solution. The state must make sure this requirement is followed by every public official and servant, and the managers of state organs must regularly enforce their subordinates to efficiently abide by these regulations. In addition, enumeration of assets (e.g. real estate, income sources, and valuables) must be maintained to effectively manage the income of each public official and quickly expose illegitimate income sources. However, it has to be carefully carried out so as to avoid being exploited to cause divisions within State organs.

Other important issues are: further promote supervision and inspection to spot and prevent corrupt behaviors, maintain constant control and inspection of government officials and public authorities, especially those who own a great deal of assets and human resources or have close links with businesses and citizens, to prevent bureaucratic and haughty behaviors, and to make timely correction to any loophole and weakness in administrative policies that can lead to corruption. Inspection, examination and supervision are among the most efficient and proactive anti-corruption solutions. President Ho Chi Minh once said: "Ninety percent of our governing mistakes results from inadequate inspection and examination. Proper supervision helps reduce possible mistakes in the future." 20

Our current system of inspection and examination is still underdeveloped. There are far too many agencies, and their inspection and examination is underperformed. These basic problems require effective solutions that are cur-

${ }^{20}$ Collection of Ho Chi Minh's works (2000), 489. 
rently under way while the Law of Inspection is being verified by the National Assembly. However, to improve the performance of inspection it is necessary to combine different methods in the overall system of supervision and inspection, which eventually would contribute to the efficiency of State management and promote the people's mastery. An informed understanding of Ho Chi Minh's ideas on the management of public officials and on the training and handling of Party members is also a preventive measure against corruption. Ho Chi Minh emphasizes:

"Public officials are main actors of public administration and every success or failure depends on their quality. "21

Corrupted officials violate moral principles and deserve to be regarded as incompetent. Therefore, it is necessary for managers to understand their subordinates so as to appoint them appropriate positions. If the appointment of officials is not based on professional skills or moral qualities but on personal affiliation, if it is not based on collective interests but on personal and "partisan" relations, then these officials will not only fail to accomplish their tasks, they will form parochial and inner circles by whatever means to take in personal gains and tread on collective interests. Therefore the selection of public officials has to be impartial, for it not only affects the officials in question but also the collective power represented by the Party and State. In reality there have been many cases in which by relying on petty tricks to acquire position, authority, power and money, public officials propagate bad practices among their peers and facilitate the spreading of corruption.

The nomination of public officials must be unbiased and objective and help expose those who take advantage of collective ideals to project their own interests, who only serve their own interest groups under the guise of common development while spreading corruption. We must base on rational criteria to appoint public officials who are not only devoted to their professional tasks but are brave enough to say no and even stand up against corruption.

${ }^{21}$ Collection of Ho Chi Minh's works (1995), 487. 


\section{Conclusion}

President Ho Chi Minh is a perfect example of a moral, diligent, frugal, righteous and impartial character. In light of the current diffusion of corruption, the usefulness and importance of Ho Chi Minh's principles become even more apparent. To follow his anti-corruption ideas is the responsibility of every public official, party member and citizen so that we can reduce as much dangerous threat to our national development as possible in this epoch of integration and development. The relentless combat against sectarianism and provincialism helps us to timely anticipate and handle misappropriation and corruption among public organs.

Harmful practices such as misappropriation and corruption currently manifest themselves under nuanced and sophisticated forms. Therefore, the party members must resolutely and determinedly avoid these practices and protect the common properties of the people, at the same time they should focus on productive and entrepreneurial efforts and contribute to socio-economic improvement. Misappropriation and corruption are contrary to revolutionary ethics, so the party members must consistently follow Ho Chi Minh's ethical standards so that transparency and solidarity among the party, state and collective organizations are upheld, and the populace has full confidence in our common project of national renewal and development.

\section{References}

Cao Van Thong/Ngoc Quoc Thai (2011): Supervision as a System to Prevent Authoritarianism in the Ruling party (Công tác giám sát góp phần ngăn ngừa nguy cơ của Đảng cầm quyền). Hanoi.

Communist Review Issue 20 (July 2002): Frugality and the Struggle against Misappropriation, Extravagance and Abuse of Power According to Ho Chi Minh's Ideas (Thực hành tiết kiệm, chống tham ô, lãng phí, chống bệnh quan liêu theo tư tưởng Hồ Chí Minh).

Communist Review issue 31 (November 2003): Scientific Conference: The reforms of the Party and anti-corruption: Experiences and solutions. (Hội thảo khoa học và thực tiễn: Xây dựng chỉnh đốn Đảng, chống tham nhũng: Kinh nghiệm và giải pháp). 
Culture and Information Publisher (ed.) (1998): General Vietnamese Dictionary. Hanoi.

Ho Chi Minh (1980): The practice of frugality and the prevention of misappropriation, extravagance and abuse of power (Thực hành tiết kiệm và chống tham ô, lãng phí, chống bệnh quan lieu). Hanoi.

Le Doan Hop (2003): Some opinions on corruption and anti-corruption (Một số ý kiến về tệ nạn tham nhũng và việc chống tham nhũng). Journal of Research exchanges issue 11.

National Politics Publisher (ed.) (1995): Collection of Ho Chi Minh works. Fourth volume. Hanoi.

National Politics Publisher (ed.) (2000): Collection of Ho Chi Minh works. Sixth volume. Hanoi.

National Politics Publisher (ed.) (2000): Ho Chi Minh Collection of works in CD. Hanoi.

Nguyen Dinh Gam (2002): The issue of corruption: causes and safeguard measures. (Tệ nạn tham nhũng: Căn nguyên sâu xa và biện pháp phòng chống). Journal of State and law issue 1.

Nguyen Huy Tan (2003): Towards efficient anti-corruption efforts among the People's Public Security. (Thực hiện lời dạy của Bác Hồ. Góp phần nâng cao hiệu quả công tác đấu tranh chống tham nhũng trong lực lượng Công an Nhân dân). Journal of Research Exchanges issue 11.

Nguyen Khac Bo (2002): Anti-corruption: immediate and long-term solutions (Chống tham nhũng, giải pháp trước mắt và lâu dài). Journal of Law and Democracy issue 4.

Nguyen Thi Doan (2002): Improve inspection among the Party to prevent and reverse corruption. (member of the Party's Central Committee, Vice President of the Central Inspection Committee). Communist Review, issue 12.

Pham Ngoc Hien/Pham Tuan Anh (2012): Questions and answers on anticorruption (Hỏi - Đáp về phòng, chống tham nhũng). Hanoi.

Tran Nghi (2014): Ho Chi Minh's ideas on the law and its application in the renovation of Vietnam (Tư tưởng Hồ Chí Minh về pháp luật và việc vận dụng trong sự nghiệp đổi mói ở Việt Nam). Hanoi.

Tran Quang Nhiep (2002): The Press in Our Struggle against the Abuse of Power and Corruption Today (Báo chí trong cuộc đấu tranh chống quan liêu, tham nhũng ở nước ta hiện na). Communist Review, Issue 11. April. 
Vo Nguyen Giap (2000): Ho Chi Minh's ideology and the revolutionary path of Vietnam (Tư tưởng Hồ Chí Minh và con đường cách mạng Việt Nam). Hanoi. 